\title{
JUBILEUSZ 50-LECIA PRACY NAUKOWEJ KS. PROF. DR TEOFILA DŁUGOSZA
}

W dn:u 24 kwietnia 1969 r. Krakowskie Srodowisko Teologiczne obchodziło uroczyście jubileusz 50-lecia pracy naukowej Księdza Profesora Dr Teofila Długosza. Uroczystość uświetnili swą obecnością J. Eminencja Ksiądz Kardynał Dr Karol Wojtyła, J. E. Ksiądz Biskup Dr Ignacy Tokarczuk i J. E. Ksiądz Biskup Dr Tadeusz Szwagrzyk. Udział w jubileuszowym obchodzie wzięli także przedstawiciele Katolickiego Uniwersytetu Lubelskiego: ks. rektor prof. dr Marian Rechowicz, dziekan Wydziału Teologicznego - ks. doc. dr Władysław Popłatek i ks. prof. dr Mieczysław Żywczyński; przedstawiciele Akademii Teologii Katolickiej w Warszawie: ks. prof. dr Eugeniusz Wyczawski i ks. doc. dr Henryk Rybus; przedstawiciele Prześwietnej Kapituły Katedralnej Krakowskiej, zaproszeni Goście, Koledzy i Uczniowie Księdza Jubilata, Profesorowie i Wykładowcy teologii w Krakowie oraz Alumni Krakowskiego Seminarium Duchownego.

Uroczystość jubileuszową otworzyło przemówienie ks. dziekana prof. dr Stanisława Grzybka. Zastosował on do Jubilata znane powiedzenie, że jedni historię tworzą, drudzy ją piszą, a jeszcze inni nad nią rozmyślają. I rzeczywiście, Ks. Prof. Długosz przez 57 lat swego kapłaństwa historię tworzył, gdy studiował i przechodził stopnie akademickie asystenta, doktora, docenta i profesora, równocześnie historię pisał, a dziś nad nią rozmyśla. Mówca życzył Jubilatowi, by Opatrzność Boża pozwoliła mu utrwalić drukiem to, co tworzył i nad czym rozmyślał, dla pożytku przyszłych pokoleń i piszących historię Kościoła.

Zasadniczy referat o życiu i działalności naukowej Jubilata wygło-sił ks. prof. dr Marian Rechowicz. Życie i praca Ks. Prof. Długosza były związane $\mathrm{z}$ dwoma archidiecezjami: krakowską i lwowską. Urodził się 
bowiem, ukończył szkołę podstawową i gimnazjum w diecezji krakowskiej. Na służbę Kościoła wstąpił w diecezji lwowskiej. Studia teologiczne odbył na Wydziale Teologicznym Uniwersytetu Jana Kazimierza we Lwowie i tam w r. 1912 przyjął święcenia kapłańskie z rąk Księdza Arcybiskupa Józefa Bilczewskiego. Otrzymawszy stypendium w r. a. 1915/16 we Frintaneum, kontynuował i pogłębiał swe studia na Uniwersytecie Wiedeńskim. Wypadki polityczne skłoniły go do opuszczenia w 1918 r. Wiednia i powrotu do kraju. Rozpoczęty w Wiedniu przewód doktorski ukończył w 1919 r. w Krakowie. Od 1919 do 1930 r. był katechetą we Lwowie. Po otrzymaniu stypendium z Funduszu Kultury Narodowej, wyjechał na rok do Rzymu, gdzie zbierał materiały dotyczące visitatio liminum polskich biskupów. Po powrocie z Rzymu został mianowany w r.a. 1931/32 zastępcą profesora na Wydziale Teologicznym we Lwowie i rozpoczą tam wykłady $\mathrm{z}$ historii Kościoła powszechnego. W r. 1937 habilitował się na tymże Wydziale. Po zawieszeniu czynności Wydziału w dniu 1 listopada 1939 r., kontynuował swe wykłady w Lwowskim Seminarium Duchownym aż do czasu jego rozwiązania w $1950 \mathrm{r}$. w Kalwarii Zebrzydowskiej. W r.a. 1949/50 powierzono mu wykłady na Wydziale Teologicznym Uniwersytetu Jagiellońskiego w Krakowie. W latach 1954 do 1957 byl profesorem historii Kościoła na Akademii Teologii Katolickiej w Warszawie. Równocześnie wykładał w Krakowskim Seminarium Duchownym. W r. 1968 przeszedł na emeryturę, kontynuując $\mathrm{w}$ dalszym ciągu pracę naukową i prowadząc seminarium naukowe.

Praca Księdza Jubilata szła kilkoma torami. Pierwszy to praca naukowa. Tematyka jego prac naukowych (szczegółowe tytuły Jego prac zostaną podane na innym miejscu) dotyczy spraw parafii, biskupstw, synodów, seminariów duchownych, wydziałów teologicznych, duszpasterstwa łącznie z kaznodziejstwem, liturgii i biografii. W okresie lwowskim jego prace dotyczyły przede wszystkim diecezyj wschodnich, a po r. 1950 zajął się problemami diecezji krakowskiej. Rozprawy naukowe Księdza Jubilata nazwał mówca ,prawdziwymi perłami na tle dotychczasowej literatury historycznej". Cechują je: krytycyzm, źródłowość, kondensacja, ścisłość niemal matematyczna i dążność do uchwycenia problemów zasadniczych. Twórczość Jubilata może służyć za wzór dla wielu młodych pracowników nauki.

Drugi tor, to jego działalność wydawnicza. Był założycielem i redaktorem „Przeglądu Teologicznego”, który przekształcono w wychodzące do dziś „Collectanea Theologica”. Był redaktorem „Miesięcznika Katechetycznego" (1923-26), redaktorem tygodnika „Ojczyzna” (1926—27), założycielem i redaktorem tygodnika "Lwowskie wiadomości parafialne” (1928-30), współpracownikiem „Gazety Kościelnej”. Był członkiem zarządów: „Stowarzyszenia Księży Prefektów”, „Towarzystwa wzajemnej 
pomocy Kapłanów” oraz Zarządu Głównego „Towarzystwa Szkoły Ludowej”. Założył towarzystwo wydawnicze „Biblioteka religijna im. Ks. Acbpa J. Bilczewskiego". Wraz z ks. prof. dr Szczepanem Szydelskim i ks. prof. dr Aleksym Klawkiem założył „Towarzystwo Teologiczne”, przemianowane później na „Polskie Towarzystwo Teologiczne”, istniejące oficjalnie do dziś w Krakowie.

Trzeci tor, to działalność patriotyczno-społeczna. Wyrażała się ona nie tylko $\mathrm{w}$ pracy duszpasterskiej, nie tylko $\mathrm{w}$ uczestnictwie i pracy w Zarządzie Głównym „Towarzystwa Szkoły Ludowej”, lecz także w pracy wydawniczej dla polskiego ludu na kresach. Opracowal i rozprowadził wśród Polaków 60 tysięcy modlitewników i 60 tysięcy kantyczek.

Po referacie składali życzenia Jubilatowi przedstawiciele katolickich uczelni w Polsce. Imieniem Katolickiego Uniwersytetu Lubelskiego dziekan ks. doc. dr Władysław Poplatek, imieniem Akademii Teologii Katolick:ej ks. prof. dr Eugeniusz Wyczawski. W imieniu Polskiego Towarzystwa Teologicznego, którego współzałożycielem był Ksiądz Jubilat, złożył życzenia jego prezes ks. prof. dr Władysław Smereka. J. E. Ksiądz Kardynał Karol Wojtyła podsumował wszystkie wypowiedzi skierowane pod adresem Jubilata, złożył Mu podziękowanie za pracę dla diecezjii, za działalność naukową i wychowawczą, życząc dalszych sukcesów.

W odpowiedzi Ksiądz Jubilat podziękował za złożone mu życzenia, a następnie dał krótką charakterystykę swej przeszłości, swych dążeń i celów naukowych. Wspominając swe studia we Wiedniu i Rzymie oraz przebieg życia podkreślił, że nie łatwa była to droga. Zajęcia katechetyczne i duszpasterskie pochłaniały dużo czasu. Zebrane z trudem materiały dotyczące visitatio liminum biskupów polskich, jak zresztą i inne materiały, nie doczekały się do dziś wydawcy. Dwie wojny światowe nie sprzyjały pracy pisarskiej i wydawniczej. We wrześniu 1939 r. został zniszczony cały nakład „Relacji” biskupów inflanckich, kijowskich, kamienieckich i unickich metropolitów kijowskich. W swej pracy naukowej i kapłańskiej starał się iść zawsze drogą prawdy, bez płytkich i złudnych kompromisów. Nie traktował niczego w sposób nierealny, lecz pragnął, by działanie było celowe i miało rzeczywistą wartość. I - dodajmy - program ten wypełnił w swym bogatym i obfitym życiu kapłańskim i naukowym.

Chór alumnów zakończył pieśnią tę piękną uroczystość jubileuszową wielkiego Kapłana, Profesora, Człowieka.

Ks. Tadeusz Wojciechowski 